\title{
Motnarrativ i holocaustundervisningen
}

\author{
Av Natalie Preminger og Yuval Regev \\ Natalie Preminger (f. 1996) og Yuval Regev (f. 1996), jødiske veivisere skoleåret 2016/17. \\ E-post: natalie.preminger@gmail.com,yuval.regev96@gmail.com
}

Holocaust er et utfordrende tema å ta for seg i undervisningssammenheng. Det er både trist, komplisert, spennende, ufattelig stort, veldig ubehagelig og delvis ubegripelig. I Norge er holocaust også fjernt for de fleste skoleelever. Temaet behandles som noe som skjedde langt unna med fremmede mennesker. Når vi nordmenn snakker om Norge i årene 1940-45, er det som oftest med en underliggende enighet $i$ at alle nordmenn var stolte motstandere av nazismen. Slik har vi, Natalie Preminger og Yuval Regev, opplevd det etter å ha bes $ø$ kt over 100 videregående skoleklasser i Norge i løpet av skoleåret 2016/17 som jødiske veivisere - et opplegg der jødiske ungdommer besøker skoleklasser med mål om å synliggjøre den jødiske minoriteten i Norge og vise mangfoldet blant dem, spre kunnskap og bidra til å redusere fordommer ${ }^{1}$.

Vi $\emptyset$ nsket å bringe temaet nærmere elevene og diskutere denne underliggende enigheten. Er heltenarrativet - historien om Max Manus, motstandsbevegelsen og krigsseilerne - den eneste måten å snakke om krigen i Norge på? Hvis ikke:

\section{FAKTA}

Undervisningsmetoden «Motnarrativ $\mathrm{i}$ holocaustundervisningen» er inspirert av tematikken i kapittel 10 og $11 \mathrm{i} /$ begynnelsen var fortellingen (2011) av $\mathrm{H}$. Breidlid og T. Nicolaisen. Her blir «parallelle og rivaliserende fortellinger» presentert som et verktøy i religionsundervisningen som kan bidra til elevenes personlighetsutvikling og læring, spesielt der de møter motstående perspektiver til sine egne tradisjoner og virkelighetsoppfatninger. Verktøyet kan også anvendes i religionskritikken. Arbeid med motnarrativer kan her bidra til å synliggjøre motstående perspektiv. For å kritisere må man først forstå, og det å se utsagn, religiøse tekster, handlinger eller historiske hendelser fra flere ulike vinkler er et verdifullt verktøy for å forstå Den Andre.

Breidlid og Nicolaisen skriver: «l sin mangfoldighet og «rivalisering» [sic] bidrar fortellingene i religionsundervisningen til å gi elevene bevissthet om at alle disse fortellingene er en del av det store fortellingsuniverset og på den måten felles fortellinger i den flerkultur vi lever i.» (s. 404). De jødiske veiviserne 16/17 brukte dette som utgangspunkt da de utarbeidet metoden «Motnarrativ i holocaustundervisningen» som presenteres her.»

1 Prosjektet Jødiske veivisere ble startet høsten 2015 og har fått tilskudd over Kommunal- og moderniseringsdepartementets budsjett av Det Mosaiske Trossamfund. Det ble senere et tiltak i regjeringens handlingsplan mot antisemittisme der to jødiske ungdommer reiser rundt i Norge og besøker skoleklasser i 90 minutters $ø$ kter. (Det kongelige kommunal- og moderniseringsdepartement, 2016). Utdanningen til stillingen som jødisk veiviser går over 10 måneder. Det innebærer to emner på HiOA: Jødedom og jødisk historie (15 p.) og Brobygging for demokratisk medborgerskap (15 p.), syv måneder i Israel på ulike utdanningsinstitusjoner der temaer som hebraisk, jødisk historie og filosofi, jødedom og mangfold vektlegges, samt 4 uker i USA for å lære om jødisk liv i USA og antisemittisme. 
Hvilke andre narrativer finnes? Og hva kan vi lære av å se på motnarrativene ved siden av hverandre?

Motnarrativ er en måte å tilnærme seg temaet som både er nyansert og faktabasert, men som også åpner for refleksjon om hvordan vi ser på historien, hvordan vi ser på hverandre og hvordan vi ser på samfunnet rundt oss gjennom briller formet av vårt eget narrativ. Gjennom prøving og feiling har vi opplevd at å holde en dialog fremfor en monolog om det norske holocaust skaper rom for å trekke linjer helt fram til sitt eget samfunn og hverdagsliv. Det er en ekstra verdi $i$ at noen som selv har sett begge narrativ «fra innsiden», i dette tilfellet jødiske nordmenn, fører ordet.

Denne teksten vil ta for seg hvordan vi brukte denne undervisningsmetoden for å snakke om det norske holocaust, og hvordan elevene responderte.

\section{MotnarRativ}

Vi hørte først om motnarrativ i emnet Brobygging for demokratisk medborgerskap ved OsloMet. På OsloMet arbeidet vi med rivaliserende fortellinger, altså fortellinger som dreier seg om samme hendelse fra henholdsvis Tanak ${ }^{2}$, det kristne Gamle Testamente og Koranen. Disse ulike bøkene har hvert sitt narrativ om hendelsen. Narrativ kan defineres som en måte å fortelle en historie på. De motstående fortellingene var motnarrativ til hverandre. Eksempelvis: bindingen av Abrahams s $ø$ n, der det i jødisk tradisjon er Isak som blir bundet, mens det i islamsk tradisjon er Ismael.

Motnarrativene ble brukt for å reflektere over og diskutere hvordan mennesker med ulik bakgrunn har ulike måter å forholde seg til historien på, at vi må være oppmerksom på dette og at vi trenger flere perspektiver for å fă et mer helhetlig bilde. Dette er et godt verkt $\emptyset$ y for å utvikle mangfoldskompetanse. Man kan ta opp ulike folkegruppers rivaliserende historier og bruke dem til å snakke om hvordan ulike mennesker ser på verden på ulike måter. En ytterligere dimensjon av dette er hvordan narrativene er knyttet til makt. Dette er i den forstand at noen narrativer blir nasjonale fortellinger som alle kjenner til, mens andre narrativer blir underkommunisert. Dette igjen kan ligge tett på en minoritets-majoritetstematikk, og er sentralt i narrativer om 2.verdenskrig i Norge.

\section{MOTNARRATIV I DEN NORSKE KRIGSHISTORIEN}

I Norge har vi et klassisk norsk krigsnarrativ. Det klassiske norske krigsnarrativet referer til det narrativet om 2. verdenskrig vi snakker mest om, og som flest forholder seg til. I klasserommet startet vi med å definere begrepet narrativ, og deretter spørre elevene hva de tenkte det klassisk norske krigsnarrativet var. I de fleste klasser fikk vi svar som motstandsbevegelsen, kongens nei, Max Manus,

2 Den jødiske bibelen 
gutta på skauen, okkupert, undertrykt. En historie om hvordan Norge ble brutalt overtatt av nazister, og hvordan nordmenn gjorde sitt ytterste for å fă friheten tilbake. Hvordan vet vi at dette er det klassiske norske krigsnarrativet? Det er bare å se på hvilke norske filmer og tv-serier om 2.verdenskrig som de siste årene er blitt produsert og sett av hundretusenvis av nordmenn: «Max Manus», «Kampen om tungtvannet», «Kongens nei» og «Den 12. mann».

Selv om dette er det klassiske norske krigsnarrativet, er det ikke nødvendigvis det eneste norske krigsnarrativet. Det var stort sett elevene også enige i. Vi fulgte opp med å introdusere et motnarrativ. Det er et vitnesbyrd fra Arnold Schermann, 12 år høsten 1942, hvor han forteller om natten da hans far og tre eldre brødre ble arrestert fordi de var jøder. «(...) Arrestert av norsk statspoliti, av nordmenn. De verste nazitypene som kunne gå i to sko», understreker Schermann (Jødisk Museum i Oslo, 2015). Han selv og moren ble ikke arrestert den natten, og klarte å flykte til Sverige før aksjonen der kvinner og barn ble arrestert. Mennene i familien ble alle drept i Auschwitz. «På hvilken måte er dette et motnarrativ?» spør vi elevene. «Her er det nordmenn som er the bad guys», sier én.

Deretter fyller vi inn med mer fakta om motnarrativet. Vi forteller om de ulike antijødiske tiltakene som ble satt i gang i Norge under okkupasjonen, og hvordan de gradvis bygget seg opp til deportasjonene av 773 jøder: Menn, kvinner og eldre og barn, fra Norge til Auschwitz. Kun 38 overlevde. Mye av informasjonen er hentet fra boken Holocaust $i$ Norge av historiker Bjarte Bruland. Et viktig poeng i presentasjonen er at arrestasjonene ble gjennomført av nordmenn, selv om det var på ordre fra den tyske okkupasjonsmakten. I de større byene spilte særlig Statspolitiet en ledende rolle på norsk side. Flere antisemittiske tiltak ble også utformet i det norske statsbyråkratiet. Selv om deportasjonen mest sannsynlig ikke ville blitt gjennomført uten tysk okkupasjon, har Bruland slått fast at holocaust i Norge forutsatte norske initiativtakere og bidragsytere.» (Bruland, 2017).

Dette er et narrativ som ikke er like lett å takle for oss nordmenn som heltenarrativet, og det har heller ikke vært snakket mye om før de siste årene. Dette motnarrativet viser nordmenn som skurker og drapsmenn, og det utfordrer nasjonalfølelsen. Historien om modige frihetsforkjempere er mye hyggeligere. Så hvorfor er det likevel viktig å snakke om dette andre narrativet i tillegg? Hva lærer vi av å se på motnarrativ i samfunnet?

\section{MotnarRativ I Dagens SAMfunN}

Det siste spørsmålet har vi stilt i ca. 100 skoleklasser, hovedsakelig på videregående trinn, over hele Norge. De får et par minutter til å diskutere det med sidekameraten $\mathrm{f} \emptyset \mathrm{r}$ vi snakker om det i plenum. For at elevene skal fordøye stoffet 
selv og kunne bruke det i egen refleksjon, er det viktig at de selv får bidra i undervisningen.

Her er selve dialogen essensiell. Holocaust er et overveldende og sensitivt tema, og vi så på det som svært viktig å snakke med elevene fremfor til dem. Dette er en uvanlig vinkling i tradisjonell holocaustundervisning, som etter vår erfaring hovedsakelig er basert på at elevene er passive mottakere av historier og perspektiver. Jeg og Yuval ønsket heller å lede en dialog blant elevene der det var rom for å sammenligne, tenke høyt, gjette, mene og stille spørsmål. Målet var å bruke motnarrativ i norsk krigshistorie som grunnlag for å reflektere over motnarrativ i dagens samfunn.

Gjennom året har vi fått et mangfold av gode kommentarer fra elevene. Her er et lite utvalg av svar vi ofte får i varierende versjoner.

\section{HVA LERER VI AV Å SE PÅ MOTNARRATIV I SAMFUNNET?}

$\ll$ En sak har alltid to sider.»

$\ll$ Hvor utrolig langt vi er villig til å gå for at den historien vi er mest komfortabel med, blir mest riktig. Jeg hadde jo aldri hørt det før nå at det faktisk var nordmenn.»

«Vi får et bedre bilde av hvordan det egentlig var.»

«Motnarrativene viser oss at det går ikke an å se på hva 'nordmenn', 'svensker', 'politimenn' gjorde, man må se på hva enkeltmennesker gjorde, for til sist er det det eneste som betyr noe. Det betyr ikke at miljøet man vokser opp $i$, ikke har noe å si, men det er ikke det eneste som definerer folk.»

«Vi skryter på oss at vi har lært av historien, men jeg tror ikke at vi har det, med tanke på flyktningkrisen og sånn.»

«Norge er opptatt av å vise det bra, men det er viktig å se det ubehagelige. Da får man empati og ser det som er mer sant. Slik modnes vi.»

«Tenker det også var tyskere som ikke var nazister, det er viktig å huske.»

Deretter stiller vi et oppfølgingsspørsmål: Hvilket narrativ er riktig? Nordmenn som helter eller nordmenn som skurker?

Ofte svarer elevene «begge er riktige» på dette spørsmålet, men vi konkluderer alltid med at ingen er riktige. Dette gjør vi med tanke på et av poengene som ofte kommer opp i diskusjonen av det forrige spørsmålet: Vi kan ikke dømme alle nordmenn til én handling eller ett forent standpunkt. Vi må se på flere narra- 
tiv, for et slikt forent standpunkt eksisterer ikke. Historien er ikke så lett som at alle nordmenn gjorde én ting, og vi må finne disse nyansene for å forstå hva som skjedde og for å se det menneskelige i historien - det vi kan kjenne oss igjen i.

Dette gjelder også nåtiden. Når vi snakker om hendelser på en måte som definerer «det forente norske standpunktet», forenkler vi hendelsen, og vi forenkler hva det vil si å være norsk. I tillegg utestenger vi mennesker med alternative narrativer. Vi må revidere dette for å ikke risikere å glemme noe av det viktigste vi har: mangfoldet. De alternative narrativene må inkluderes i vår felles oppfatning for en mer realistisk og nyansert virkelighetsforståelse.

Denne forenklingen « nordmenn er» ligger i dagligtalen vår, og mange vil si at det er pirkete å kreve en nyansering. Alle vet jo at ikke alle nordmenn gjorde det samme under krigen. Vi vil likevel argumentere for at måten vi snakker til daglig, i stor grad definerer hvordan vi tenker. Jo mindre vi nevner nyansene og motnarrativene, desto mer vil vi glemme dem. Da kan vi risikere å glemme hvor kompliserte årene 1940-45 var, og glemme de historiene som kanskje er mer ubehagelige, men minst like viktige. Historieløshet kan være farlig, og kan bidra til diskriminerende holdninger.

I tillegg kan denne forenklingen si noe om mye mer dagligdagse fenomener: Det å bruke enkle, men uriktige narrativer som «amerikanere er dumme», «jøder er smarte» og «homofile har bra klesstil» konsekvent i hverdagen bidrar til generaliserende tankegang og underbygger fordommer, selv om vi ikke mener forenklingene bokstavelig. Motnarrativene kan bidra til å nyansere fordommene, stereotypiene og de nasjonale fortellingene, og dette kan gjelde både på individ-, gruppe- eller nasjonalt nivå.

\section{Til slutt}

For mange skoleelever i dag er holocaust et tema som er fjernt og høytidelig. Tragedien med ingen over eller ved siden av. Det er lett å tenke at «dette er så trist og viktig, men det har jo ingenting med meg å gjøre». Da har vi feilet i holocaustundervisningen. Motnarrativ er en måte å bringe det nærmere elevene på, og bidrar til forståelsen av at det ikke skjedde «langt unna med fremmede mennesker», men at vi kan lære av det og at det fortsatt er aktuelt å snakke om i dag. Spesielt viktig er det at det skjer i en åpen dialog der elevene selv får dele egne tanker og meninger.

Når vi reflekterer over at ikke alle nordmenn var motstandsmenn og ikke alle nordmenn var nazister (de fleste var ingen av delene når det kommer til stykket), forstår vi at det er plass til begge narrativene når vi snakker om krigen. Det ene stryker ikke ut det andre. Vi kan ikke velge enten den stolte eller den skamfulle historien, vi må la dem stå side om side og gi oss et mer helhetlig bilde av historien som har bidratt til å forme Norge. Dette viser oss mangfoldet 
i historien og lar oss lære av våre feil. Å studere motnarrativ i historien hjelper elevene også til å se motnarrativ i dagens samfunn. Å øve på å se saker fra flere sider menneskeliggjør perspektiver som er annerledes og bidrar til elevenes forståelse av samfunnsdebatten og dens mange nyanser. Dette er ikke minst viktig $i$ arbeidet med å forebygge diskriminerende holdninger.

Hvis man forstår at mennesker med en annen bakgrunn kan ha en annen måte å fortelle en historisk hendelse på enn man selv har, så forstår man at også ens eget narrativ er formet av ens egen bakgrunn. Etter dette kan man фve seg på å se på seg selv utenfra, enten som individ eller som befolkning. Dette er klasserommet en ypperlig arena for. Ved å sammen utforske hvilket narrativ man selv innehar og hvor det kommer fra, blir det enklere å forstå motnarrativene som møter en, og hvor de kommer fra. Dermed blir ikke virkeligheten bare det jeg ser, men heller et produkt av alle motnarrativene i samspill.

\section{LitTERATUR}

Breidlid, H., og Nicolaisen, T. (2011). I begynnelsen var fortellingen. 2. utgave. Kapittel $10-11$.

Det kongelige kommunal- og moderniseringsdepartement (Oktober 2016): Handlingsplan mot antisemittisme 2016-2020. Norge.

Bruland, B. (2017) Holocaust $i$ Norge. Dreyers forlag.

Jødisk Museum i Oslo/NRK (2015): Husk oss til livet (dokumentar). 